\title{
Ny og bedre medisin mot hjertesvikt
}

\section{Et kombinasjonspreparat med angiotensinreseptorantagonist og nepri- lysinhemmer gir lavere dødelighet enn enalapril hos pasienter med hjertesvikt.}

Medikamenter som hemmer renin-angiotensin-systemet gir redusert dødelighet ved hjertesvikt. En ny type medisin som blant annet hemmer enzymet neprilysin kan redusere dødeligheten ytterligere. Dette viser en nylig publisert studie, finansiert av Novartis (1). Neprilysin degraderer blant annet natriuretiske peptider, bradykinin og adrenomedullin, som alle kan tenkes å bidra til effekten.

Nesten 8500 pasienter med hjertesvikt og ejeksjonsfraksjon under $40 \%$ ble randomisert til enten et kombinasjonspreparat med angiotensinreseptorantagonist og neprilysinhemmer eller enalapril i tillegg til sin standard hjertesviktbehandling. Studien ble stoppet tidlig fordi gruppen som fikk kombinasjonspreparatet hadde lavere dødelighet enn gruppen som fikk enalapril. Etter to år var $13,3 \%$ av pasientene $\mathrm{i}$ første gruppe og $16,5 \%$ av pasientene $\mathrm{i}$ den andre gruppen

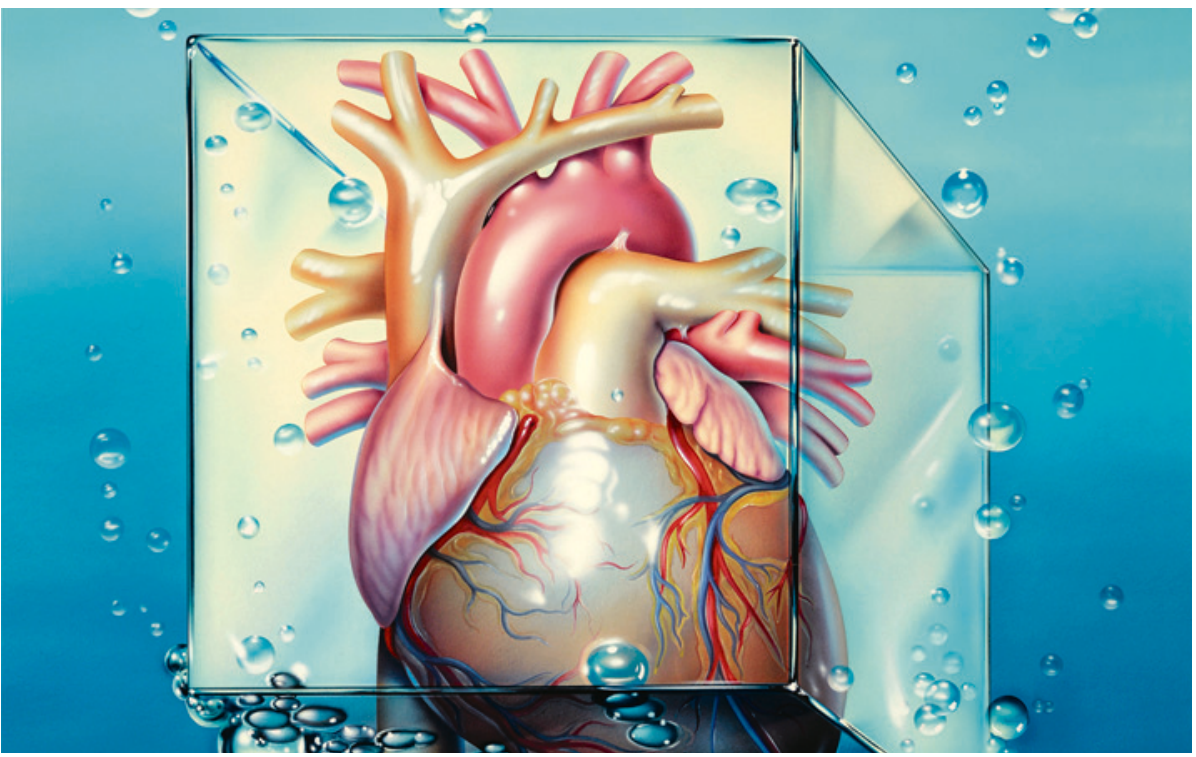

Illustrasjonsfoto: Science Photo Library

døde av kardiovaskulære årsaker (hasardratio 0,80; $95 \%$ KI 0,71-0,89). Kombinasjonspreparatet mildnet symptomene, ga færre fysiske begrensninger og lavere risiko for innleggelser grunnet hjertesvikt. Det ga mer hypotensjon, men mindre nyresvikt, hyperkalemi og hoste sammenliknet med enalapril.

- Denne studien er veldig spennende, og resultatene virker overbevisende, sier professor Finn Olav Levy, Avdeling for farmakologi ved Universitetet i Oslo og Oslo universitetssykehus. Han er også leder for K.G. Jebsen-senter for hjerteforskning.

- Fra et klinisk ståsted er sammenlikningen med ACE-hemmeren enalapril i doser som i seg selv gir høyere overlevelse svært relevant. Fra et vitenskapelig ståsted ville det vært interessant å sammenlikne med valsartan, altså den angiotensinreseptorantagonisten som inngår i kombinasjonspreparatet. Det er svært interessant at denne behandlingen viser så god effekt, mens en tidligere studie med en annen neprilysinhemmer, omapatrilat, som samtidig er en ACE-hemmer, ikke viste gunstige resultater, sier han.

- Studien kan åpne døren for ny hjertesviktbehandling og viser samtidig at vi har mye å lære om balansen mellom de ulike effektene av renin-angiotensin-systemet, natriuretiske peptider og andre vasoaktive peptider, sier Levy.

\section{Lise Mørkved Helsingen}

Tidsskriftet

\section{Litteratur}

1. McMurray JJV, Packer M, Desai AS et al. Angiotensin-neprilysin inhibition versus enalapril in heart failure. N Engl J Med 2014; 371: 993-1004.

\section{Kardiovaskulær sykdom og kjønnsforskjeller}

\section{Middelaldrende menn og kvinner \\ har omtrent samme livstidsrisiko \\ for kardiovaskulær sykdom, men \\ det er store forskjeller i sykdoms- manifestasjon og alder ved syk- domsdebut.}

Forekomsten av kardiovaskulær sykdom er ulik hos kvinner og menn, men forskjeller i livsstidsrisiko og når sykdom inntreffer for første gang er ikke tilstrekkelig kartlagt. Dette er nylig undersøkt i en prospektiv kohortstudie med over 8400 personer over 55 år uten kjent kardiovaskulær sykdom i Nederland (1).

Etter opptil 20 års oppfølging var livstidsrisikoen for kardiovaskulær sykdom for menn ved 55 års alder beregnet til $67 \%$. For kvinner var den $66 \%$. Risikoen for første tilfelle av slik sykdom hos menn var $27 \%$ for koronar hjertesykdom, $23 \%$ for cerebrovaskulær sykdom, $15 \%$ for hjertesvikt og 2,3\% for død av annen kardiovaskulær sykdom. For kvinner var tallene henholdsvis $17 \%$, $30 \%, 18 \%$ og $2,1 \%$.

- Dette er interessante og viktige funn fra en studie utført med gode metoder. Det er rimelig å anta at funnene også gjelder for den norske befolkning, sier professor Kaare Harald Bønaa, som er overlege ved Klinikk for hjertemedisin ved St. Olavs hospital. - Studien viser at to av tre middaldrende menn og kvinner før eller senere vil bli rammet av kardiovaskulær sykdom. Menn rammes tidligere enn kvinner og ofte først av koronarsykdom, mens kvinner rammes ofte først av hjerneslag eller hjertesvikt.

En svakhet ved studien er at man kun har inkludert personer over 55 år, sier Bønaa. - Den beskriver derfor ikke den totale livstidsrisikoen for kardiovaskulær sykdom. Likevel er studien en påminnelse om at kardiovaskulær sykdom er en dominerende årsak til sykdom og død for både menn og kvinner, sier han.

Trine B. Haugen

Tidsskriftet

Litteratur

1. Leening MJ Ferket BS, Steyerberg EW et al Sex differences in lifetime risk and first manifestation of cardiovascular disease: prospective population based cohort study. BMJ 2014; 349: g5992. 